Artigos/Articles

\title{
Inclusive practices and policies in language teacher education courses
}

\section{Práticas inclusivas e políticas nos cursos de formação inicial de professores de línguas}

\author{
Betânia Passos Medrado' \\ Dilma Mello ${ }^{2}$ \\ Juliana Reichert Assunção Tonelli ${ }^{3}$
}

\section{ABSTRACT}

The current legislation regulating basic education in Brazil (Brasil, 2013) and the inclusion of students with specific educational needs in regular schools (Brasil, 2015) warrant some reflections on the discourses and actions in the field of language teacher education. We have observed that the implementation of inclusive practices in Brazilian schools has been a time-consuming process as it implies not only changes in public policies, but also - and maybe primarily - several kinds of transformation in educational contexts. Considering the broad spectrum of students'specific educational needs, given the innumerable types of pathologies and their nuances, as well as keeping in mind the assumption that teachers can only

1. Universidade Federal da Paraíba, João Pessoa, Paraíba - Brazil. https://orcid.org/00000002-8275-6607. E-mail: betamedrado@gmail.com.

2. Universidade Federal de Uberlândia, Uberlândia, Minas Gerais - Brazil. https://orcid. org/0000-0002-7769-3760. E-mail: mello.dilma@gmail.com.

3. Universidade Estadual de Londrina, Londrina, Paraná - Brazil. https://orcid.org/00000001-5102-5847. E-mail: teacherjuliana@uol.com.br. 
create some space for inclusive practices in the classroom if their education is based on critical, autonomous, and informed thinking (Celani, 2010), we consider it to be essential to explore the language teacher education landscape. It seems important to highlight that our understanding of inclusive practices is related to the process of identifying and reflecting on what social-affective, ethical, and pedagogical changes are needed, not only providing accessibility and architectural changes as is usually done. However, this perspective still requires some debate on the language teacher education courses in our country. In this paper, we discuss the inclusive practices, programs, and studies carried out at three Brazilian universities: Federal University of Paraiba, State University of Londrina, and Federal University of Uberlândia. Our aim is to analyze the way inclusive matters have been or can be incorporated into the pedagogical project, the teacher practicum, and/or the individual projects of teacher educators in the institutions mentioned in this paper.

Key-words: public policies; inclusive practices; specific educational needs; language teacher education.

\section{RESUMO}

A legislação vigente que normatiza a Educação Básica no Brasil (Brasil, 2013) e a inclusão de alunos com necessidades educacionais especificas nas escolas regulares (Brasil, 2015) provoca uma reflexão sobre os discursos e as ações no âmbito da formação de professores de línguas. Observamos que a concretização de práticas inclusivas nas escolas brasileiras tem se apresentado como um processo moroso, pois implica não apenas mudanças nas políticas públicas, mas, sobretudo, transformações de várias ordens nos contextos educativos. Considerando o amplo espectro das necessidades educacionais especificas dos alunos, haja vista os inúmeros tipos de patologias e suas nuances, pautamo-nos no pressuposto de que só uma formação calcada no pensar crítico, autônomo e informado (Celani, 2010) possibilitará ao professor criar espaços que sejam propícios a uma sala de fato inclusiva. Parece importante ressaltar que nossa compreensão das práticas inclusivas está relacionada ao processo de identificação e reflexão sobre quais mudanças socioafetivas, éticas e pedagógicas são necessárias e não apenas prover mudanças arquitetônicas e de acessibilidade. Contudo, essa perspectiva ainda requer debates acerca da formação de professores de línguas em nosso país. Neste artigo, discutimos práticas inclusivas, ações e pesquisas desenvolvidas em três universidades brasileiras (Universidade Estadual 
de Londrina, Universidade Federal de Uberlândia e Universidade Federal da Paraíba). Nosso objetivo é analisar como a temática da inclusão tem sido ou pode ser incorporada aos projetos pedagógicos, à prática docente elou aos projetos individuais de professores-formadores nas instituições mencionadas neste texto.

Palavras-chave: políticas públicas; práticas inclusivas; necessidades educacionais especificas; formação de professores de línguas.

\section{Introduction}

As the title of this article proposes, our aim is to reflect upon inclusive practices, programs, and scientific studies carried out at three Brazilian universities: Federal University of Paraíba (UFPB), the State University of Londrina (UEL) and the Federal University of Uberlândia (UFU). The analysis of these three contexts may shed some light on the following question: How are these institutions in Brazil dealing with pedagogical accessibility and overcoming the huge gaps between public policies and language teacher education curricula?

In the past few years, institutional policies have been largely based on the Brazilian Inclusion Law (LBI; Brasil, 2015), which the government approved in order to bring together dozens of other laws, decrees, and conventions already guaranteeing the rights of people challenged by different physical and/or intellectual needs in Brazil. The LBI is, to a certain extent, the document that most extensively treats the rights of this group in our country. The law's text, more specifically, Chapter IV of LBI, which focuses on education, states several requirements for teachers and teacher education programs. A few aspects the law considers are as follows:

Art. 27. Education constitutes the right of the disabled person, ensuring an inclusive educational system at all levels and lifelong learning in order to achieve the maximum possible development of their physical, sensory, intellectual, and social skills and abilities, according to their characteristics, interests, and needs.

Sole paragraph. It is the duty of the State, the family, the school community, and society to ensure quality education for the disabled, placing them safe 
from all forms of violence, neglect, and discrimination [our translation] (Brasil, 2015:96). ${ }^{4}$

V. The adoption of individualized and collective measures in environments that maximize the academic and social development of students with disabilities, favoring access, permanence, participation, and learning in educational institutions [our translation] (Brasil, 2015:106). ${ }^{5}$

LBI reinforces that inclusive education not only means gaining access to regular schools and universities (e.g., access to education), but also implies that participation and achievement should be expected. It is worth pointing out that achievement is understood in our study in its broad sense, meaning not only outcomes through assessment tools, but also meaningful learning and development. As the law brings about the idea of the adoption of individual and collective measures in order to maximize the social and academic development of students with specific needs, it definitely poses (and imposes) at least three tasks for all kinds and levels of teacher education programs: contents and materials must be adapted, teachers should work in order to provide a positive academic atmosphere, and specific teaching skills are needed in order to accomplish all this.

All things considered, our own studies and our various experiences at the institutions where we work have shown serious shortcomings; much remains to be done to promote inclusion in academic contexts. Yet we have to consider that some progress has been made, as we discuss next.

4. Art. 27. A educação constitui direito da pessoa com deficiência, assegurados sistema educacional inclusivo em todos os níveis e aprendizado ao longo de toda a vida, de forma a alcançar o máximo desenvolvimento possível de seus talentos e habilidades físicas, sensoriais, intelectuais e sociais, segundo suas características, interesses e necessidades de aprendizagem.

Parágrafo único. É dever do Estado, da família, da comunidade escolar e da sociedade assegurar educação de qualidade à pessoa com deficiência, colocando-a a salvo de toda forma de violência, negligência e discriminação (Brasil, 2015:96)

5. Art. 27. A educação constitui direito da pessoa com deficiência, assegurados sistema educacional inclusivo em todos os níveis e aprendizado ao longo de toda a vida, de forma a alcançar o máximo desenvolvimento possível de seus talentos e habilidades físicas, sensoriais, intelectuais e sociais, segundo suas características, interesses e necessidades de aprendizagem (Brasil, 2015:106). 


\section{Methodological and Theoretical Perspectives}

This paper is the result of qualitative research carried out during the 2016 academic year and based on data the authors collected over the course of approximately five years at three Brazilian institutions (i.e., UFPB, UEL, and UFU). Although the observations focused on some inclusive practices developed for undergraduate modern language courses at the three institutions investigated, other activities at these universities were also taken into account.

In order to obtain the data, we assessed i) institutional information available at the official websites; ii) some extension projects; iii) academic events held at the universities; iv) documents and numbers related to inclusive practices; and v) the curricula proposed (or not) within the context of the universities. When possible, the available information, projects, and activities carried out by the department officially in charge of inclusive matters at the universities were also considered. We also examined the lived experiences (Clandinin, 2007) in some of the projects, events, and undergraduate courses as a source of support for our construction of knowledge about inclusive education within the institutions.

As such, our research can be characterized as documentary and experiential research (Clandinin, 2007) through which we sought to understand the tentative inclusive stories these three studied universities have constructed alongside its communities, looking particularly to experiences in undergraduate modern language courses.

Some theoretical basis helped us better understand the concepts of inclusive education and accessibility with which we worked, in addition to Brazilian legislation related to inclusive concerns.

In addition to what is stated by LBI (Brasil, 2016), our work is based on the idea of inclusion as a process of creating some spaces to which different people, challenged by different situations, may feel comfortable belonging. Wenger (2001) posed the idea of belonging while discussing ways of participation within a community of learning and practice. Although Wenger does not work on inclusive practices, his idea of belonging seems to fit our understanding of what inclusion can be in our educational contexts. In addition, we considered the 
perspective of world travelling as proposed and discussed by Frye (1983) and Lugones (1987). According to these authors, in order to avoid being arrogant to those living in different worlds, one needs to learn how to travel to others' world as a way of understanding them through their own eyes and not from an outside point of view.

It seems important to highlight our use of specific terms to address inclusive matters related to the different people to "be included." Most Brazilian legislation (e.g., LBI) and some educational documents (e.g., BNCC) apply the terms students with special needs or students with disabilities. However, the word "special" has been strongly criticized by those whom it describes as well as by researchers in the field. One argument is that an adjective is not sufficient to provide a precise personal and social identification. Recently, authors such as Uzeda (2012) and Penha (2017, individual communication), have concluded we are all human beings and that needs to come first. As a result, the term people with disability has been emphasized. Considering that both perspectives are officially used by the government and some important authors in the field, we decided to use them interchangeably, although we do not completely agree with their use. We understand that the term disability implies a negative notion, suggesting that society is divided in a group of people with all abilities and another group of disabled people, as if this were accurate. In fact, as human beings, we all live with abilities and disabilities. Therefore, and following the lead of some authors, we also consider the following terms: people challenged by (e.g., height, weight, vision, hearing) as socially used by Canadian people in their everyday lives, and people with different specific needs or people with different individual needs, as posed and discussed by Oliveira (2016) and Mello (2017). We understand these terms better reflect identity matters and democratically and educationally propose a new and different inclusive perspective that we think is extremely necessary in the field of inclusive studies. However, as the field is still being constructed, we also understand it is important to discuss these terms with limiting teacher educators to using a single one, although the debate on this matter still needs to be highlighted in our regular school contexts. This theme is itself a source for entirely new paper as it falls beyond the scope of our article. 


\section{Inclusive Practices and Programs at Universidade Federal da Paraíba}

According to the last census (Brasil, 2010), more than 45 million people in Brazil declared they had some kind of specific need. In the state of Paraíba, for instance, the number of students with specific needs enrolled in regular schools is increasing every year. In 2015, approximately 6000 students with specific educational needs (Paraíba, 2015) enrolled in regular schools, meaning that a great number of these students will soon enter our universities.

For example, in 2009, Olavo, ${ }^{6}$ a visually impaired student who finished regular school in 2012, discussed his feelings about his future at college ${ }^{7}$ :

After we leave regular school ... we will be deciding our lives at college, won't we? And at the university sometimes it is very difficult too ... because there... there are more people ... It is huge and the thing about the place... to get around and ... the regular schools are important so that when we arrive at the university we will be used to it ... to the noise ... to the place ... to the professors that surely won't have... qualified professors ... We certainly will have a little difficulty right? Like in regular schools ... But these difficulties are very important so that we arrive at college at ease too $^{8}$ [our translation] (Corpus ALDEI, 2009)

Olavo's words highlight the expectations students with specific educational needs (SEN) have in relation to their future academic life. Although the responsibility of inclusion cannot lie solely on teachers' shoulders - rather, the whole school community, parents, classmates,

6. Olavo was interviewed in 2009, when he was in the ninth grade. In 2018, he finished his undergraduate course majoring in radio journalism at UFPB.

7. Data collected as part of undergraduate scientific research projects (PIBIC/CNPQ 2009-2014) and more recently by the Research Group ALDEI (Agir de Linguagem, Docência e Educação Inclusiva).

8. depois que a gente sair da escola regular... a gente estará decidindo a nossa vida na universidade né? e na universidade às vezes é muito difícil também... porque lá... : tem mais pessoas... muito grande e a questão assim do ambiente pra se locomover e as escolas regulares são importantes pra que a gente quando chegar na universidade já esteja acostumado né?.. com o barulho... com o local... com os professores que com certeza nas universidades não vão ter... professores também capacitados... com certeza a gente deve ter um pouco de dificuldade né? como nas escolas regulares... mas são muito importantes pra gente chegar na universidade tranquilos também (Corpus ALDEI). 
and school staff should be involved - as teachers we have to be committed to finding ways so that all students, not only those with specific educational needs, can benefit from being in the classroom. After all, students cannot be denied the right to study or learn (Brasil, 2015).

Olavo was aware of the fact that his education would not be easier at the university because most professors are not prepared to provide students with inclusive learning experiences. In the case of UFPB, for instance, more than 550 students have been diagnosed with different kinds of educational needs, such as visual or hearing impairment, attention deficit/hyperactivity disorder, autism, dyslexia, and other emotional and social needs. Most of them are supported by the programs offered by the Inclusion and Accessibility Committee (CIA) ${ }^{9}$ at UFPB, which aim to provide students with specific educational needs (CIA refers to them as supported students) with assistance inside and outside the classroom. The program selects supporters, who are students able to take responsibility for helping SEN students with their academic tasks. In addition to guiding students with mobility challenges, supporters help SEN students with activities in the classrooms, mediate their interactions with teachers, request adaptive materials or assistive technology tools when needed from different departments at UFPB. These supporter students get monthly scholarships and a certificate for participating in the project. Depending on each student's needs, more than one supporter may be required. Thus, UFPB currently has 202 supporter students responsible for 105 students with specific educational needs.

SEN students are not the only ones to benefit from the program; supporter students and so-called normal students also benefit. Ramp slopes for wheelchairs and tactile paving for the blind are important efforts, but not enough, as inclusive practices mean more than that. We believe that it is always a matter of attitude, and getting acquainted with the differences (Skliar, 2006) is a way to trigger an inclusive attitude. Janine, a student with visual impairment who majored in Portuguese literature at UFPB, was assisted by the CIA program. She explained that, 
when you see someone with a disability, ask them if they need help; if they accept, ask them the best way to help. When you see me with someone, do not ask the other person the questions you should ask me. Talk to me- - talk to me directly. That the teacher [...] talk to me, let him talk to me about the best way to carry out classroom activities. [...] You do not need to feel sorry for me. A disability is not a tragedy in my life. It's just part of my identity. Besides, it is not being inferior, and I am not superior. People treat us like we're from a different world. Many times teachers want to make things easier for us, perhaps because they do not know how far we can go, perhaps because they do not know to what extent they can be malleable or to what extent they can make demands of $\mathrm{me}^{10}$ [our translation] (Corpus ALDEI, 2017).

Policies are coming down the government pipeline on a daily basis and in a top-down manner. Overcoming gaps between these policies and our reality means being open to understanding those students who are entering the university. Above all, it is important to ask questions and resolve doubts, as Janine emphasized - namely, being able to try and being able to communicate/talk about and exchange ideas. Thus, inclusive education does not require the teacher to adopt a generous attitude or pitiful eye as Janine clearly states, but rather demands a willingness to understand the characteristics and limitations of a SEN student and to do something to enable the student to reach, as the law states, "the maximum of his[/her] development."

It is high time teachers respond pedagogically to the increasing number of SEN students who are enrolled in regular schools and universities. Another relevant concern is how ethically and professionally we teachers want/need to respond to the policies. In all contexts, including undergraduate courses in public or private universities, inclusion is always about being open to learning about

10. Quando você vir uma pessoa com deficiência, pergunte se ela precisa de ajuda, se ela aceitar, pergunte a ela qual a melhor maneira de ajudar. Quando você me vir acompanhada por alguém, não faça a outra pessoa as perguntas que você deveria fazer a mim, dirija-se a mim, fale comigo diretamente. Que o professor [...] converse comigo, que ele dialogue comigo sobre a melhor maneira de desempenhar as atividades em sala de aula. [...] Você não precisa sentir pena de mim, a deficiência não é uma tragédia na minha vida. Ela é só parte da minha identidade. Além de eu não ser inferior, eu não sou superior. As pessoas tratam a gente como se a gente fosse de outro mundo. Muitas vezes os professores querem passar a mão na nossa cabeça, talvez por não saberem até onde nós podemos ir, talvez por não saberem até que ponto eles podem ser maleáveis ou até que ponto eles podem exigir de mim (Corpus ALDEI, 2017). 
differences with/from others. On the one hand, this idea should be considered as the source of everyone's attitudes and also an asset to education. On the other hand, we cannot deny that it is always a challenge to include as it can be uncomfortable or even petrifying to do so, as Dantas (2014) mentioned in her dissertation when she interviewed in-service teachers who claimed "I don't know how to deal with that student.... I don't know how to interact with him, I don't know how to provide him with adapted lessons or materials." The questions that arise among pre-service and in-service teachers are always the same: Are we prepared to be inclusive? When and where do we teachers learn to be inclusive? Who can teach us to be inclusive, to deal with our dilemmas and anxieties when somebody tells us that a student who cannot hear is going to come to our classes?

At UFPB, five years of investigation (PIBIC-CNPq, 2009-2014), coordinated by one of the authors of this paper, demonstrated that if a teacher is able to provide a positive atmosphere in class, encourage all students to interact in class, work together, and learn what they are expected to learn at their own pace, the teacher not only adopts inclusive practices, but also has a certain attitude toward teaching. Therefore, undergraduate students should be aware or be encouraged to observe that not everyone in class can see pictures, not everyone can listen to the audio, and not everyone can sit on the floor to play a game; in addition, some students may take longer to finish an exercise because they need somebody to help they accomplish the task.

Considering the urgent needs to revisit language teacher education programs curricula, the projects mentioned thus far have focused on different aspects of teaching foreign language to SEN students. The five-year project designed different objectives (cf. Medrado, 2014), such as analyzing interactive, cognitive, and affective aspects of SEN students; investigating their learning strategies; systematizing necessary teaching skills and knowledge to teach visually impaired students; looking into pre-service teachers' identities; and adapting materials and accessible tools for language lesson. The research took place at UFPB and at Instituto dos Cegos da Paraíba. ${ }^{11}$ 
In addition to the development of these projects, other actions were fostered in order to promote the interactions of undergraduate students majoring in modern languages with teachers from regular schools. For example, in 2011, the 1st Seminário de Formação de Professores de Língua Estrangeira e Educação Inclusiva ${ }^{12}$ was organized. Undergraduate students and teachers from modern languages and pedagogy courses as well as teachers from regular schools joined the seminar, where they had the opportunity to learn together about the Braille system, accessibility, inclusive legislation, and other relevant topics. In addition, as part of the projects, from 2012 to 2013, 42 visually impaired students participated in English, French, and Spanish lessons at UFPB and Instituto dos Cegos da Paraíba. These lessons were planned and taught by pre-service teachers who participated in the projects as scholarship holders and volunteers. Currently, our extension language classes for the community still include visually impaired students, which have had important and definite impacts on the practices of our undergraduate students teaching these extension groups.

Findings from various studies (cf. Medrado, 2014; Dantas and Medrado, 2014a; Dantas and Medrado, 2014b; Celani and Medrado, 2017) have shown that inclusion is mainly a matter of attitude. Simply put, the basic principle of inclusion is to be able to understand and deal positively with any differences. In a broad sense, inclusive education means that, as a teacher, the individual is able to provide everyone in his/her class with learning opportunities according to their needs and possibilities (intellectual, physical, etc.) as well as respond to individual needs. Such an approach applies for all learners, not just those who have some kind of physical or intellectual impairment.

This has been an important aspect considered in our foreign language teacher education program nowadays. The investigations carried out at UFPB and the number of dissertations and monographs produced in the past few years (more than 20 on inclusion matters as of 2018) have shown how relevant the experiences in both the projects and the extension program at the Foreign Languages Department (DLEM) have been in order to encourage reflection on inclusive practices in 
regular schools. This awareness has definitely contributed to expanding our internship spaces. Since 2016, 27 students have been able to develop their internship activities at Instituto dos Cegos da Paraíba as part of an agreement between this institution and UFPB (Agreement Note $\mathrm{n}^{\circ}$ 072/2014/UFPB). Finally, in 2017, the Research Group ALDEI (Agir de Linguagem, Docência e Educação Inclusiva-CNPq, 2017) ${ }^{13}$ started its activities as a result of students' and teachers' increased interest in looking into different aspects of inclusion. Due to this increasing interest in inclusive practices, as well as efforts in our postgraduate course, several pieces of research have been defended, as shown in Chart 1.

Chart 1 - Dissertations and Theses on Inclusive Issues carried out at PROLINGUFPB

\begin{tabular}{|c|c|c|c|}
\hline $\begin{array}{l}\text { Research } \\
\text { Level }\end{array}$ & Title & Author & Year \\
\hline Dissertation & $\begin{array}{l}\text { Teaching representations for teaching } \\
\text { foreign languages to students with } \\
\text { visual impairment }\end{array}$ & $\begin{array}{l}\text { Dennis Souza da } \\
\text { Costa }\end{array}$ & 2018 \\
\hline Dissertation & $\begin{array}{l}\text { Language and Autism: multimodality } \\
\text { in the school context }\end{array}$ & $\begin{array}{l}\text { Cássio Kennedy de Sá } \\
\text { Andrade }\end{array}$ & 2017 \\
\hline Dissertation & $\begin{array}{l}\text { Reconfigurations of teaching actions: } \\
\text { teaching foreign language to students } \\
\text { with specific visual needs in light of } \\
\text { the ISD and Work Sciences }\end{array}$ & $\begin{array}{l}\text { Náthaly Guisel } \\
\text { Bejarano Aragón }\end{array}$ & 2016 \\
\hline Dissertation & $\begin{array}{l}\text { Multimodal interactions in the } \\
\text { language clinic: the child with Down } \\
\text { syndrome }\end{array}$ & $\begin{array}{l}\text { Ivonaldo Leidson } \\
\text { Barbosa Lima }\end{array}$ & 2016 \\
\hline Thesis & $\begin{array}{l}\text { Deaf teacher: discourse about his } \\
\text { practice }\end{array}$ & $\begin{array}{l}\text { Viviane da Silva } \\
\text { Gomes }\end{array}$ & 2015 \\
\hline Dissertation & $\begin{array}{l}\text { Teaching visually impaired students: } \\
\text { conflicts and development }\end{array}$ & Rosycléa Dantas & 2014 \\
\hline Dissertation & $\begin{array}{l}\text { Acquisition of writing by the deaf: a } \\
\text { look at curricular adaptation }\end{array}$ & $\begin{array}{l}\text { Thereza Sophia } \\
\text { Jácome Pires }\end{array}$ & 2013 \\
\hline Dissertation & $\begin{array}{l}\text { The functioning of joint attention in } \\
\text { the interaction between a mother and } \\
\text { her blind child }\end{array}$ & $\begin{array}{l}\text { Renata Fonseca Lima } \\
\text { da Fonte }\end{array}$ & 2011 \\
\hline
\end{tabular}

Source: Authors 


\section{Inclusive Practices and Studies carried out at Universidade Estadual de Londrina}

In this section, we discuss some of the teacher education initiatives that have been carried out at Universidade Estadual de Londrina.

UEL has a department responsible for offering students any kind of special treatment; this department is named Núcleo de Acessibilidade ${ }^{14}$ (NAC/UEL). However, our experience shows that teaching a modern foreign language to students with SEN has unfortunately not been seen as an urgent theme in the field of English teachers' educational programs. Nevertheless, for those teacher educators with some experience working with students with any kind of specific educational needs in the classroom, the reality, in this case, seems to be much more convincing than any policy program.

As isolated and limited as they have been, some initiatives at UEL were unchained due to two main reasons: 1) our own experience teaching English at basic education and 2) some undergraduate and postgraduate students who showed interest in teaching and researching English while working with young learners with SEN. Among the actions, we highlight two events and some attempts concerning English teachers' initial education-more specifically, their teaching practicum.

The first event in the area of foreign language teacher education at UEL was the I Ciclo de Palestras sobre transtornos globais do desenvolvimento: implicações para o ensino e a aprendizagem, ${ }^{15}$ which was carried out on three mornings, during each of which participants, including undergraduate students, could listen to professionals from the educational and brain physiotherapist fields discuss some aspects of the cognitive features of the brain as well as the behavior of those diagnosed with some special educational needs.

In 2016, the II Ciclo de Palestras sobre transtornos globais do desenvolvimento: implicações para o ensino e a aprendizagem

14. Accessibility Center.

15. Cycle of lectures on global developmental disorders: implications for teaching and learning. 
e I Seminário sobre politicas de inclusão em língua estrangeira ${ }^{16}$ took place. During the second edition, we could listen to important researchers in the field and also hear from basic education teachers, who provided testimonies concerning this challenging activity. They highlighted the urgent need for programs to offer opportunities so that pre-service teachers can have a chance to understand better how to teach foreign languages to students in need of special attention. The great impact of such events was gathering teachers and researchers together so they could share experiences and, most importantly, shed light on new possible ways to meet special students' needs.

Another initiative that has been offered to the students is the possibility to develop their teaching practicum in educational contexts with children with SEN. Since 2014 undergraduate students majoring in English who choose having this experience during their pre-service teaching are supervised by teacher educators who agree to do so. However, this possibility is not formally registered in the course program. Hence, it depends on the good will and to what extent teacher educators feel comfortable in supervising the teaching practicum in that field, as they have not been prepared to teach English to students with SEN themselves.

Such events and initiatives have helped not only undergraduate students become more aware of the presence of individuals with SEN in basic education (primary and secondary school), but also teacher educators who have accordingly redesigned the course. The new curriculum for undergraduate students in the English teacher education program at UEL includes some disciplines, in the format of workshops, in which the undergraduate students connect with the theoretical aspects of teaching English to students with SEN.

In addition to the actions described thus far, we consider it important to present the scientific research concerning English teaching and/or teacher education carried out thus far at different levels of teacher education at the State University of Londrina, as shown in Chart 2:

16. I Cycle of Lectures on global development disorders: implications for teaching and learning and I Seminar on inclusion policies in foreign languages. 
Chart 2 - Scientific research concerning English teaching and/or teacher education carried out at State University of Londrina

\begin{tabular}{|c|c|c|c|}
\hline Research level & Title & Author & Year \\
\hline Thesis & $\begin{array}{l}\text { "Dyslexia" and the teaching- } \\
\text { learning of the English language }\end{array}$ & $\begin{array}{l}\text { Juliana Reichert } \\
\text { Assunção Tonelli }\end{array}$ & 2012 \\
\hline Dissertation & $\begin{array}{l}\text { Policies for Teaching English to } \\
\text { the Deaf }\end{array}$ & $\begin{array}{l}\text { Leonardo Neves } \\
\text { Correa }\end{array}$ & 2013 \\
\hline $\begin{array}{l}\text { Undergraduate } \\
\text { papers }\end{array}$ & $\begin{array}{l}\text { Neuroeducation and the teaching } \\
\text { of English as a foreign language } \\
\text { to individuals with Asperger } \\
\text { syndrome }\end{array}$ & $\begin{array}{l}\text { Eduardo Pimentel da } \\
\text { Rocha }\end{array}$ & 2014 \\
\hline $\begin{array}{l}\text { Undergraduate } \\
\text { Scientific } \\
\text { research }\end{array}$ & $\begin{array}{l}\text { Adaptation of didactic sequence } \\
\text { for teaching English to a child } \\
\text { with autism spectrum disorder }\end{array}$ & $\begin{array}{l}\text { Otto Henrique Silva } \\
\text { Ferreira }\end{array}$ & 2016 \\
\hline Dissertation & $\begin{array}{l}\text { Possibilities and challenges } \\
\text { in the education of English- } \\
\text { speaking teachers to individuals } \\
\text { with Asperger syndrome }\end{array}$ & $\begin{array}{l}\text { Eduardo Pimentel da } \\
\text { Rocha }\end{array}$ & 2016 \\
\hline $\begin{array}{l}\text { Undergraduate } \\
\text { Scientific } \\
\text { research }\end{array}$ & $\begin{array}{l}\text { English Teaching for Visually } \\
\text { Impaired and/or Low Vision } \\
\text { Children: A Study on Inclusive } \\
\text { Education }\end{array}$ & Izabella Ribeiro Bill & 2018 \\
\hline Dissertation & $\begin{array}{l}\text { The development of a didactic } \\
\text { unit for teaching English in the } \\
\text { context of inclusion with blind } \\
\text { children }\end{array}$ & $\begin{array}{l}\text { Juliana da Silva Gui- } \\
\text { marães Biagini }\end{array}$ & 2018 \\
\hline Dissertation & $\begin{array}{l}\text { Inclusion of visually impaired } \\
\text { students: proposal of Spanish- } \\
\text { language didactic sequence for } \\
\text { elementary education }\end{array}$ & $\begin{array}{l}\text { Thays Regina Ribeiro } \\
\text { de Oliveira }\end{array}$ & 2018 \\
\hline
\end{tabular}

Source: Authors

All research displayed in Charts 1 and 2 indicate attempts to support those interested in understanding specific areas of SEN and English teaching while showing some possible ways to create and adapt didactic materials in order to teach the language to those with SEN.

\section{Inclusive Practices and Programs at Universidade Federal de Uberlândia}

One of the first spaces for inclusive practices at the Federal University of Uberlândia (UFU) was the foundation of the Centre 
for Teaching, Research, Extension Programs, and Special Education Care (CEPAE), originally created and managed by members of the education faculty. This center has offered several kinds of services and activities to the academic and local communities since its foundation, such as technical consulting service to instructors, researchers, and professionals interested in inclusive educational practices as well as for special needs students, in addition to organizing and promoting different types of events on inclusive education (e.g., conferences, seminars, lectures, and courses).

It is located in a very small room at the education faculty building, and its work team is formed by a director, a few administrative assistants, and ten LIBRAS ${ }^{17}$ interpreters. The work team is responsible for attending all four campuses' faculties at the university. Its website (www. cepae.faced.ufu.br) provides some suggestions for websites that offer general information on inclusive matters as well as information for deaf and visually impaired people. CEPAE also has a resource room where students and faculty members can get assistance. Table 1 summarizes the courses and projects currently offered by the center.

Table 1 - Courses and Projects offered by Center for Teaching, Research, Extension Programs, and Special Education Care

\begin{tabular}{|l|l|}
\hline Courses & Projects \\
\hline $\begin{array}{l}\text { Training Brazilian Sign } \\
\text { Language instructors }\end{array}$ & $\begin{array}{l}\text { Volunteer readers: anyone can volunteer to be a reader and } \\
\text { help blind and low vision people. }\end{array}$ \\
\hline $\begin{array}{l}\text { LIBRAS - Brazilian } \\
\text { Sign Language }\end{array}$ & $\begin{array}{l}\text { Health LIBRAS: a project aimed at helping deaf students } \\
\text { get care from doctors and psychologists, for example. }\end{array}$ \\
\hline Braille & \\
\hline $\begin{array}{l}\text { Interpreters (Braille and } \\
\text { Portuguese) }\end{array}$ & \\
\hline $\begin{array}{l}\text { Assistive Technologies } \\
\text { Mobility }\end{array}$ & \\
\hline $\begin{array}{l}\text { Tutoring for deaf } \\
\text { students }\end{array}$ & \\
\hline $\begin{array}{l}\text { Highly skilled students } \\
\text { (Gifted students) - EAD }\end{array}$ & \\
\hline
\end{tabular}

Source: CEPAE (Available at: www.cepae.faced.ufu.br. Accessed: August 2018)

17. Brazilian Sign Language. 
Although the center represents the beginning of inclusive education at the Federal University of Uberlândia, some tensions have emerged. One issue is the fact that it is impossible to attend to the number of students and faculty members from the university campus, as previously mentioned; as a result, students are not well aware of the center, whereas mainly university professors/researchers are. The inability to deal with different students' needs provokes some misunderstandings concerning its role among the university community, mainly from instructors who sometimes believe special needs students are to be taught by the center's members instead of professors, for example.

In addition to CEPAE, another example of inclusion at the Federal University of Uberlândia has been the undergraduate course on Portuguese and LIBRAS teacher education (Portuguese degree, with focus on Brazilian sign language). This four-year face-to-face course was created in 2013 (Resolution 16/2013 by the University Council), but its first term started in 2014, with 30 tuition-free vacancies offered on a yearly basis. It has a team of eight professors, three of whom are deaf. Some extension courses are offered to local and academic communities, including Portuguese language for deaf people, LIBRAS, and writing courses in Portuguese. As it is still a brand new undergraduate course at the university, much has to be investigated to construct some knowledge about its quality and its challenges. However, some issues have already been faced: there are not enough interpreters (LIBRAS and Portuguese) to assist deaf instructors and students (only eight interpreters assist all university departments and campuses); there are not assistive technologies available; and the institution itself is not completely prepared to be inclusive considering the activities that deaf instructors and students are supposed to accomplish.

In the area of foreign language teacher education at UFU, particularly in the English field, a subject matter related to inclusive education was offered, but after the third offering, the faculty member team decided it was too difficult for freshmen, and it was replaced with the course Foreign Languages. Nowadays UFU is modifying the course curriculum, and a professor has suggested a new subject for inclusive education and assistive technologies; although it was accepted as part of the curriculum in progress, the majority of the group decided it will be a non-mandatory discipline. Thus, it will only be offered depending 
on the particular interest of a professor, which means it might never be offered. On the other hand, a graduate course on inclusive practices in the teaching of languages has been regularly offered in the post graduate Linguistics and Applied Linguistics program. A similar course was also offered in an online specialization course on English teacher education in 2017, which targeted English teachers from local public schools. It seems relevant to highlight that the professor in charge of the courses offered is a legally blind person interested in inclusive education matters. Chart 3 shows some dissertations and theses supervised by that professor.

Chart 3 - Dissertations and Theses on Inclusive Issues carried out at PPGELUFU

\begin{tabular}{|l|l|l|l|}
\hline Research Level & Title & Author & Year \\
\hline Thesis (MA) & $\begin{array}{l}\text { I have a deaf student: experience } \\
\text { of Portuguese teaching in private } \\
\text { class context }\end{array}$ & $\begin{array}{l}\text { Elaine Amélia de M } \\
\text { Maria de Morais }\end{array}$ & 2017 \\
\hline Thesis (MA) & $\begin{array}{l}\text { Stories of assisting students with } \\
\text { special individual needs }\end{array}$ & $\begin{array}{l}\text { Nilza Maria de } \\
\text { Oliveira }\end{array}$ & 2016 \\
\hline $\begin{array}{l}\text { Dissertation } \\
\text { (Ph.D.) }\end{array}$ & $\begin{array}{l}\text { Literacies and Deafness: stories } \\
\text { of a hearing teacher within the } \\
\text { deaf world }\end{array}$ & $\begin{array}{l}\text { Judith Mara de Sou- } \\
\text { za Almeida }\end{array}$ & 2015 \\
\hline Thesis (MA) & $\begin{array}{l}\text { The reading of the world through } \\
\text { the senses: stories of teaching, } \\
\text { learning, and visually impaired } \\
\text { students }\end{array}$ & $\begin{array}{l}\text { Judith Mara de } \\
\text { Souza Almeida }\end{array}$ & 2008 \\
\hline
\end{tabular}

Source: Available at PPGEL www.ileel.ufu.brs

As this information suggests, only a few actions have been related to inclusive issues, and there may not be much interest on the part of university members at the Federal University of Uberlândia. As a result, a lot remains to be done.

More recently, some new possible spaces for inclusive practices have been created at this institution. One of them is the research group Language Teaching and Inclusive Practices (GPELPI-Grupo de Pesquisa Ensino de Línguas e Práticas Inclusivas) registered at $\mathrm{CNPq}$ in 2017. The group consists of professors/researchers from different 
educational institutions in the country: three universities located in different regions (the ones discussed in this paper, UFPB, UEL, and UFU, which are located in the northeast and southeast parts of Brazil) and two federal institutes (IFTM and IFSC from the southeast and southern parts of the country). GPELPI's goals are mainly connected to five research perspectives: teaching languages to deaf, deafblind, and blind (or legally blind) students; teaching Portuguese as a second language to deaf students; pre-service and continuing teacher education; inclusive practices and assistive technologies as well as digital technologies; and LIBRAS, including both the teaching and learning processes. The joint and collaborative work proposed in this research group might promote increased inclusive actions at each institution involved as well as the number of academic meetings, courses, and publications related to this topic, but may focus primarily on the creation of a community of inclusive practices and inclusive learning.

All of the inclusive actions described in this section are equally relevant, but maybe the most relevant one has been the actions organized and promoted by the Educational Tutorial Program (ETP/ PET - Programa de Educação Tutorial) managed by UFU's faculty. There are 30 ETP/PET offerings at the Federal University of Uberlandia, which develop a meaningful number of activities related to inclusive education in different areas. In 2015, a multidisciplinary colloquium on inclusive education that took place pointed out some tensions about the experience of being legally blind at the university and in everyday life. In 2016, during the third meeting of PETs at UFU, a lecture on inclusive education and diversity highlighted some affirmative actions. In the same year, a lecture was offered on the challenges faced by a legally blind professor and a professional using a wheelchair. Finally, in 2018, a short-term course on inclusion and assessment was proposed for Languages Week, organized by the literature group's ETP/PET. These activities are very relevant due to the visibility they achieved among university and local communities, mainly because they are organized and attended by a significant number of students from all fields. 


\section{Inclusive Experiences: Challenges and possibilities at UFPB, UEL, and UFU}

The experiences described in this paper demonstrate that there are different ways of creating spaces for inclusive practices in the three institutions studied. Although most of the inclusive experiences lived at UFPB and UEL are more directly related to undergraduate courses on language teacher education, inclusive experiences at UFU come from other stances, such as the postgraduate course, and mainly from ETP/PET, for instance. On the other hand, some similarities emerge considering the activities taking place within the context of our undergraduate course (major in languages). In this specific landscape, inclusive activities are strongly linked to the curriculum proposed (or not proposed), which highlights some concerns about inclusive practices and teacher education. However, this inclusive awareness does not come from the group as a team, but only from an individual's engagement of a single researcher-instructor, which underscores the need to raise awareness among all members of literature courses so more spaces for inclusive practices can be created.

This lack of participation and engagement might be a result of the development of just a few works related to accessibility and inclusive practices within the field of language teacher education in our country. However, how can knowledge be constructed without creating more opportunities and spaces in which we can all live these experiences and learn from them? It is also important to highlight that knowledge in this area is still being constructed for and listened to by deaf, blind, and legally blind people, among others, as posed by Mello (2017), which might help all of us learn what inclusive education can be. As Lugones (1987) concluded, the need to travel to the world of others might help us all not only learn about them, but also from them and with them.

Although the data indicate that there is much to be done concerning language teacher education in undergraduate courses, UFPB's actions show some possible ways of promoting inclusive education within the language teacher education field, including especially powerful ways of incorporating inclusive practices. Concerning postgraduate courses, the great majority of research carried out at UEL and UFU show language 
teachers' interest in the field. As we tried to demonstrate in the charts, the investigations are based on the authors' questions concerning their own teaching practices or immediate contexts. From our point of view, such a scenario shows that, in our context of initial language teacher education courses, students do not have the chance to study specific subjects on inclusion; so, when they graduate and have to teach SEN kids, they do not know what or how to teach them. As a result, they tend to go back to the university in order to carry out research as a way to better understand and build alternatives to inclusive practices.

In addition to the activities taking place in the undergraduate and postgraduate courses, it seems important to highlight the activities proposed by some other institutional contexts, such as those organized by ETP/PET in the language group and those offered by the Center for Teaching, Research, Extension Programs, and Special Education Care or by any other department in charge of inclusion at each university. As already mentioned, these activities usually achieve great visibility because they are offered to the whole academic community. The data show the possibility for some joint projects to be proposed and carried out by modern language courses, ETS/PET, and those centers responsible for inclusive assistance at universities, such as the CIA at UFPB. Another joint experience to be reinforced and continued might be sharing inclusive stories lived by different modern language courses and different universities, as the authors of this paper have done. The more partnerships we are able to construct, the more we might be able to increase inclusive practices and construct knowledge in the field in our institutions. Thus, instead of continuously depending on individual actions, we can construct some institutional foundation for some more powerful inclusive work.

\section{Final Remarks}

This paper sought to present inclusive practices, programs, and investigations carried out at three Brazilian universities: Federal University of Paraíba (UFPB), the State University of Londrina (UEL), and the Federal University of Uberlândia (UFU). The following question guided our discussion: How are these institutions in Brazil dealing with pedagogical accessibility and overcoming the huge gaps 
between public policies and our language teacher education programs? In order to achieve such a goal, we described some actions implemented and studies developed at the universities where we teach.

In general terms, the main focus in the three contexts has been to broaden the debate in order to raise the community's awareness of the realities in which students with SEN are inserted. Based on the experiences shared in this paper, it is also possible to state that, although laws exist concerning inclusive education in our country, the initiatives in foreign language teacher education programs come much more from individuals' or small groups' interests. This certainly reveals the urgent need to increase the number of actions in order to overcome the attitudinal barriers in relation to the unknown, the laws, the institutions, and the people.

Although we feel like ants engaging in shy and, seemingly, less important work, we do believe, just as the swallows do, that collaborative work can strengthen everyone involved in the issues discussed in this paper, especially those we want and need to understand better: ourselves, as researchers and teacher educators; others, including our students, who are teachers in pre-service education programs; and those still considered to be different in a society that insists on deciding who is who.

\section{References}

BRASIL, 2013. Diretrizes Curriculares Nacionais da Educação Básica. Secretaria da Educação Básica, MEC: Brasília.

BRASIL, 2015. Lei Brasileira de Inclusão. Estatuto da Pessoa com Deficiência. Brasília.

CELANI, Maria Antonieta Alba, 2010. Perguntas ainda sem resposta na formação de professores de línguas. In: GIMENEZ, Telma e MONTEIRO, Maria Cristina de Góes (Org.) Formação de Professores de línguas na América Latina e Transformação Social, Campinas: Pontes Editora. p. 57-67.

CELANI, Maria Antonieta Alba; MEDRADO, Betânia Passos. 2017. Diálogos sobre Inclusão: das políticas às práticas na formação de professores de línguas estrangeiras. Campinas: Pontes Editora. 
CLANDININ, Jean D. 2007. Handbook of Narrative Inquiry: mapping a methodology. Thousands Oak, CA: Sage Publications.

DANTAS, Rosycléa, 2014. Ensinar a alunos com deficiência visual: conflitos e desenvolvimento. Dissertação de Mestrado, UFPB.

DANTAS, Rosycléa; MEDRADO, Betânia Passos. 2014a. Uma leitura interacionista sociodiscursiva do ensino de inglês a alunos com deficiência visual: representações de uma professora. Revista Eutomia, 14, 221-239.

.2014b. O dizer sobre o fazer pedagógico: vozes e sentidos em um contexto de inclusão, Revista Investigações, 27 (2).

MEDRADO, Betânia Passos. 2014. Deficiência Visual e Ensino de Linguas Estrangeiras: políticas, formação e ações inclusivas. Campinas: Pontes Editora.

FRYE, Marilyn, 1983. Politics of Reality. Essays in Feminist Theory. Freedom, CA: The Crossing Press.

LUGONNES, Maria, 1987. Playfulness, World-Travelling and Loving Perception. Hypatia, 2(2), 2-19.

MELLO, Dilma. 2017. Discente e Docente com Baixa Visão: a minoria invisível na Escola. In: CELANI, Maria Antonieta Alba; MEDRADO, Betânia Passos (Orgs.). Diálogos sobre inclusão: das políticas às práticas na formação de professores de línguas estrangeiras. 1 ed. Campinas: Pontes.

OLIVEIRA, Nilza Maria. 2016. Historias de Atendimento a Alunos com necessidades especiais individuais. Dissertação de Mestrado defendida no Programa de Pós-graduação em Estudos Linguísticos da Universidade Federal de Uberlândia.

PARAÍBA. 2015. Censo Escolar. Secretaria da Educação Estadual da Paraíba.

SKLIAR, Carlos. 2006. A inclusão que é "nossa" e a diferença que é do "outro". In: RODRIGUES, David. Inclusão e educação: doze olhares sobre a educação inclusiva (Org.). São Paulo: Summus. p. 16-34.

UZEDA, Sheila de Quadros; MIRANDA, T. O. 2012. Papel de Mulheres/ Mães Na Inclusão de Crianças com Deficiência Visual na Educação Infantil. In VII Encontro Nacional dos Pesquisadores da Educação Especial, 2012, Sao Carlos, SP.

WENGER, Etienne. 2001. Communities of Practices: learning, meaning and identity. Cambridge: University Press.

Recebido em: 30/08/2018

Aprovado em: 22/03/2019 